Vol.: 6 Issue: 4 Year: 2018, pp. 790-805

Citation: Dönbak E.R. (2018), Organizational Ecology of Accommodation Populations That Take Place In Turkey, BMIJ, (2018), 6(4): 790-805 doi: http://dx.doi.org/10.15295/bmij.v6i4.293

\title{
ORGANIZATIONAL ECOLOGY OF ACCOMMODATION POPULATIONS THAT TAKE PLACE IN TURKEY
}

Eda Rukiye DÖNBAK ${ }^{1}$
Received Date (Başvuru Tarihi): 28/09/2018

Accepted Date (Kabul Tarihi): 29/10/2018

Published Date (Yayın Tarihi): 04/01/2019

\section{ABSTRACT}

The present study aims at taking an ecological approach to explain general and private types of accommodation organizations' ecological movements in Turkey. Distribution Statistics for Certified Accommodation Facilities by Their Type issued by the Ministry of Culture and Tourism of Turkey for the period between 1990 and 2015, was used as data source. General and private organization types were classified by using this data and previous studies in literature. In this study repeated measure ANOVA test is used in order to investigate the significant differences between general and private accommodation groups' upward trends between years of 1990 - 2015. When the data is tested independently based on years it is found that there is significant difference only in the group of private organizations. There was an upward trend in all groups compared to the years whereas this difference was significant only in the group of private organizations. The results can aid organizations strategically implementing their business plans.

Keywords: Management, Business Management, Tourism Management, Organizational Ecology

JEL Codes: M21, M5, Z

\section{TÜRKIYY'DE YER ALAN KONAKLAMA POPÜLASYONLARINA AİT ORGANIZASYON EKOLOJILERI}

$\ddot{O} Z$

Bu çalı̧̧ma, örgüt ekolojisi yaklaşımı çerçevesinde Türkiye'deki genel ve özel türlerdeki konaklama organizasyonlarının ekolojik davranışlarını açıklamayı amaçlamaktadır. Türkiye Cumhuriyeti Kültür ve Turizm Bakanlığl tarafindan 1990 - 2015 yılları arasında oluşturulan, "Belgeli Konaklama Tesislerinin Tür ve Sinıflarına Göre Dağllım İstatistikleri” araştırma verileri olarak kullanılmıştır. Veriler ile birlikte ilgili literatür kullanılarak genel ve özel konaklama türleri sınıflaması yapılmıştır. Bu çalışmada, genel ve özel konaklama gruplarının 19902015 yılları arasındaki yükselme eğilimleri arasındaki önemli farklılıkları araştırmak amacıla tekrarlı ANOVA testi kullanılmıştır. Verileri yıllara göre ayrı olarak test ettiğimizde, sadece özel konaklama örgütleri grubunda anlamlı bir fark elde edilmiştir. Tüm gruplarda ylllara göre yükselme eğilimi görülürken, bu fark sadece özel konaklama örgütleri grubunda anlamlı olmuştur. Araştırma sonuçlarının iş yönetim stratejilerini oluşturmada yöneticiler için fayda sağlaması beklenmektedir.

Anahtar Kelimeler: Yönetim; Işsletme Yönetimi; Turizm Işsletmeciliği; Örgüt Ekolojisi

JEL Kodlart: $M 21, M 5, Z$

\footnotetext{
${ }^{1}$ Dr. Öğr. Üys, Adıyaman Üniversitesi, Turizm Fakültesi, edonbak@ adiyaman.edu.tr $\quad \underline{\text { http://orcid.org/0000-0002-1752-0390 }}$
} 


\section{INTRODUCTION}

The expansion of various services given in different type accommodation firms, have intensified competition for scarce resources among private and general types of accommodation organizations. To increase their chance of survival they try to take advantage of new organizational forms. For example, Hilton Hotels produce different types of services for tourists and businessmen by running Hampton By Hiltons, Hilton Garden Inn, Doubletree By Hilton, Homewood Suits By Hilton, Hilton Hotels \& Resorts, Embassy Suite Hotels, Home2 Suites by Hilton and Hilton Grand Vacations (https://www.hilton.com.tr/haberler).

Compared to international chain hotels, smaller national establishments seem to offer more focused services. In recent years, there are two trends in the hospitality industry, one of which is the increase in the number of establishments entering the market and the other is also directed to boutique hotels. (Jones et al., 2013). Boutique hotels having a market segment out of the reach of large chain hotels, operate in a market in which small-scale accommodation businesses operate and they are distinguished from large-scale organizations with their unique room design offering a specific concept and furniture, suitable for such a concept (Strannegard $\&$ Strannegard, 2012). Allastair et al. (1996), note that private accommodation types will play an important role in the future and this type of accommodation is classified according to their facilities (number of rooms, location selection, the period they are open for business), number of employees, dining services, ownership type, and performance level (seasonal business, occupancy rate, profitability, number of overnight stays).

Having investigated the trends available in Asia-Pacific Region in hospitality industry since 90s, Hing et al. (1998), reported that the number of hotels specialized in services such as meetings and conferences (MICE), apart hotels, eco-hotels, boutique hotels and B\&B hotels that are suitable for tourists who are looking for an experience-focused vacation with a substantial travelling motivation, has been increasing ever since. Callan \& Fearon (1997), in their study, defined another private accommodation type, the plateau and ranch houses, as hotels owned by private entrepreneurs which have no more than 60 rooms with very special housing function and which are located at an attractive location in a plateau, village or ranch. Another type of accommodation is the thermal hotels which serve for the needs of the healthcare industry, which has been developing recently.

Distinguished from hotels offering medical services (Meditel), these thermal hotels offer services such as natural thermal water, diet programs under supervision of the personnel, 
rehabilitation services, skin care and beauty programs along with services such as accommodation and dining (Han, 2013; Chen, \& Tzeng, 2011; Lu \& Shiu, 2009; Hsieh, 2007). Trade in body care and health services and products, which are of international quality, is considered a new and a very profitable industry especially in developing countries (Han, 2013; Heung et al., 2011; Bookman \& Bookman, 2007).

It is estimated that the golf tourism market is the world's most developed sports tourism market with a trade volume of \$20B (Humphreys, 2014). Moital \& Machado (2013), noted that the satisfaction of golf tourists depends on nine factors and one of these factors is the availability of golfing facilities in the complex and stated that golf tourism plays an important role in reducing the seasonal impact especially on destinations depending on "sun and sea" tourism. According to the definition of Ministry of Culture and Tourism of Turkey, golf hotels consists of golf course, heating and practice areas along with supporting facilities located on areas suitable for the international norms of the golf sport. Golf hotels and thermal hotels are also incorporated into the star rating system in Turkey depending on the building features, service types, activities and quality of the facilities.

Aim of this study, is to examine ecological events of private accommodations rather than at the individual organization research level by using organizational ecology approach. Tourism scholars have devoted considerable attention to explain private accommodation types (Han, 2013; Jones et al., 2013; Strannegard \& Strannegard, 2012; Callan \& Fearon, 1997, Allastair et al. 1996), however, no earlier research has applied organizational ecology perspective to examine upward tendency of private type accommodation organizations. Hijalager, (2000) noted, organizational ecology has offered rich content in order to understand the environmental behavior of organizations operating in the tourism industry better. In her first research Hijalager (1999), discusses the dynamics of regional tourism development. In her second research, Hijalager (2000), focused study on explanations for the occurrence of life events in the restaurant sector by applying organizational ecology approach. Andersson et al. (2013), addresses the sustainability of festival populations from the perspective of organizational ecology. Getz and Andersson, (2016), employed organizational ecology theory for analyzing whole populations of festival and events. Researches in this theory generally use longitudinal data and investigate the entry and exit of firms to the populations available in an industry, and their survival rates (Hijalager, 2000; Loree, 2008; Erdil, Kalkan \& Alparslan, 2010; Xu, 2017). 


\section{LITERATURE REVIEW}

\subsection{Organizational Ecology}

The organizational ecology theory was first introduced in the "Population Ecology of Organizations" by Hannan \& Freeman in 1977 (Kaya \& Ataman, 2013, p.59; Getz \& Andersson, 2016). Mathew (2015), associated organizational ecology with open system theory by explaining "organizations and their external environments are in a constant state of 'material' exchange in the form of information and other feedback, leading to active and adaptive changes in each of their future conditions". It was noted before in the definition of population as part of the organizational ecology, and it is also a result of the fact that organizations in a population are a group of organizations which use similar resources and operate in a similar manner. Population density, organizational competition, distribution of natural resources and government regulations are governed by relevant social processes which leads to increased or decreased population concentration (Kaya \& Ataman, 2013; 60). Ivery (2007), also noted that organizational ecology is theoretical framework for analyzing survival and interdependency of organizations.

Organizational ecology investigates any group of living organisms and their relationship with their environment (Carroll \& Hannan, 1989, 2000). Organizational ecology involves the hypotheses namely, the rise of organizations with characteristics consistent with new conditions and the demise of organizations with characteristics inconsistent with new conditions as a result of environmental selection in an evolving organizational world (Ersoy et al., 2015). Addressing the survival of organizations in the population they belong to, the Darwinist theory explains the structural change organizations go through as a process involving phases such as diversification, selection, popularity and competition from an evolution point of view (Baum ve Amburgey, 2002). Examples of organizational ecology perspective commonly used in relevant studies include beer manufacturers, publishing, record companies, automobile manufacturers and banks (Carroll \& Swaminathan, 2000). Organizational diversification, when it has a positive impact on the organization, may attribute a value to the organization and it may result in the survival of the organization and popularity of selected organizations come to mean that they are legitimate and they survive (Perrow, 1986).

\subsection{Population Density and Density Dependence}

In organizational ecology, population can be defined as a group of organizations with similar activities as well as a group of organizations with a shared form competing for the same 
resources which interact with each other (Kaya \& Ataman, 2013; 60). Population density is defined as the total number of firms operating in the population (Carroll \& Hannan, 1989, p.524; Aldrich \& Ruef, 2006, p.212; Anderson et al. 2013; Getz \& Andersson, 2016; Xu, 2017). Density dependence represents vital rate as a result of number of organism (Anderson et al. 2013). The structure of the organizational forms available in a population, involves factors such as population density level and variety of the resources, population dynamics (Carroll, 1985; 1264); while the legitimacy of the organizational forms involves homogeneity or heterogeneity of the population (Petersen \& Koput; 1991); and the population density involves liquidation, organizational evolution (Carroll \& Hannan, 1989) and competition (Carroll, 1985).

Stretesky et al. 2012; Carroll \& Hannan, 2000, claims that "organizations may differentiate in a flexible manner in order to become environmentally consistent and the level of homogeneity of a population decreases as the differentiation increases thus increasing the competition between organizations". Carroll \& Swaminathan, (2000), researched interdependence relation between micro beer producers and factory producers of USA's beer producer populations. Hijalager (2000), suggested that fast food establishments and restaurants are interdependent, compete each other and they could be categorized as subcategories of food population because they appeal to different customer segments and have different developmental mechanisms. Similarly Hijalager (2000), Xu (2017), assumed as sub categories to party and non party newspapers. In this study private and general accommodation firms are classified as sub category of accommodation population in Turkey and they are assumed to be in a dependency relationship.

\subsection{Sub Populations of Turkey's Acommodation Population}

However it is commonly accepted that a classification is hard for tourism products and services as the criteria used involves different structures (Serrano, Turrion \& Velazquez, 2014), 'star rating' system is the most commonly used system in international platforms (MartinFuentes, 2016). Price, quality, service types, physical facilities and the income of the hotel, are classification criteria (Martin-Fuentes, 2016). Allastair et al. (1996), notes that private accommodation types will play an important role in the future and that this type of accommodation is classified according to their facilities (number of rooms, location selection, the period they are open for business), number of employees, dining services, ownership type, and performance level (seasonal business, occupancy rate, profitability, number of overnight stays). In their study researchers (Pearce \& Moscardo, 1992; Allastair et al., 1996) report that 
an accommodation business needs to meet three essential features in order to be considered as a private structure business, which are as follows:

“a) Selection of experienced human resources which can meet the individual needs of the guests (i.e., reception, dining, making information available, management and communication)

b) The location to be able to meet the needs of the guests (ranches or wildlife areas), organization properties (facility with a cultural or historical value), or ability to offer its guests an experience (handcrafts workshops or wildlife watch, etc.)

c) The accommodation facility is most commonly run by its owner and the fact that it is not a part of a chain or group, plays an important role in its classification as a private organization".

Another factor behind the fact that accommodation businesses may be classified under types other than the ones defined by the regulations, is the location selection of those businesses. Proximity to the market, proximity to supplier and resources, status of workforce supply, operational costs, infrastructure facilities, legal regulations and incentives are among the classification criteria (Uludağ \& Deveci, 2013). Aktaş (2002), reported that tourism motivation factors plays a role in the differentiated types of accommodation businesses. Chu \& Choi (2000), tried to explain the diversity of hotels from demand side and emphasized six factors for hotel preference of tourists; service quality, physical facilities, rooms, reception, dining and recreation, and safety. Study by Zang et al., (2012), reported a significant relationship between international tourist arrivals in each state which has a tourist attraction and the money spent by these tourists and the facility location decision made by international chain hotels. In Turkey, The Ministry of Culture and Tourism explains the status of each hotel type with regards to these factors (http://yigm.kulturturizm.gov.tr/TR,9860/turizm-belgeli-esisler.html). Accommodation types considered private organizations in Turkey as per the regulations of the Ministry of Culture and Tourism of Turkey, includes their location selection, architectural characteristics of the building, number of rooms, thematic design in rooms, characteristics of the furniture available in rooms, sports, health and recreational facilities, dining services (availability of dining and beverage options suitable for Turkish dining culture, meals and beverages consisting of homemade options, traditional Turkish cuisine menu, options from international cuisines, menus for other cuisines). 


\section{METHOD}

\subsection{Data Collection and Measurement}

With the aim of measuring population density of accommodation organizations in Turkey, general and private sub population data are obtained from the "Distribution Statistics for Certified Accommodation Facilities by Their Type and Class" issued by the Ministry of Culture and Tourism of Turkey (http://yigm.kulturturizm.gov.tr/TR,9860/turizm-belgeliesisler. html) for the period between 1990 and 2015. In this study sub categories of accommodation populations are classified under general 1, general 2 and private accommodation types by using Ministry's and previous studies' classifications.

Table 1: Accommodation Type Groups

\begin{tabular}{|c|c|c|c|}
\hline Groups & \multicolumn{2}{|c|}{ Group 2} & Group 3 \\
\hline \multirow{15}{*}{$\begin{array}{c}\text { Accommodation Types } \\
\text { Under Each Group }\end{array}$} & \multicolumn{2}{|c|}{ General Organization Groups } & Private Organization \\
\hline & Hotels with star rating & Pensions & Holiday Resorts \\
\hline & Tourism Complexes & Training \& Education & Private Facilities \\
\hline & & Facilities Caravan Parks & Thermal Hotels \\
\hline & & Apart Hotels & $\begin{array}{c}\text { Thermal Holiday } \\
\text { Resorts }\end{array}$ \\
\hline & & Hostels & Thermal Apart Hotels \\
\hline & & Motels & Golf Hotels \\
\hline & & & Mountain Houses \\
\hline & & & Auberges \\
\hline & & & Plateau Houses \\
\hline & & & $\begin{array}{c}\text { Ranch or Village } \\
\text { Houses }\end{array}$ \\
\hline & & & $\begin{array}{c}\text { Type B Holiday } \\
\text { Resorts }\end{array}$ \\
\hline & & & Campings \\
\hline & & & Boutique Hotels \\
\hline & & & Boutique Villas \\
\hline
\end{tabular}

Table 1 is formed based on Ministry's data and literature on diversity of accommodation establishments. Criteria such as properties of the facility locations, ability to serve for custom needs of guests, offering an experience to guests, contribution to sustainable tourism, characteristics of the personnel, features of dining and beverage services (Allastair et al., 1996), 
attracting for touristic purposes along with accommodation needs (Aktaş, 2002), room design, themes available in rooms, use of furniture complementary to the room design (Strannegard,\& Strannegard, 2012), offering customized services, being able to meet specific guest needs, not being a member of a chain, high quality equipment and furniture available in rooms (Jones, Day \& Quadri - Felitti, 2013), and increasing service quality from 1-Star to 5-Star when the business is rated with star rating system (Martin ve Fuentes, 2016), were all compliant with the criteria defined by the Ministry and these criteria were used to group accommodation business types in this study. The most important discrimination between general first and second sub group is the star rating criterion. Accommodation sub populations available in Table 4 under the $1^{\text {st }}$ and $2^{\text {nd }}$ group are organizations with a general business strategy and they have heterogeneous market targets while the ones under the $3^{\text {rd }}$ group are private organizations with a private business strategy and they have homogeneous market targets.

In Hijalager's (2000) study, organizational ecology approaches are divided into four groups as demographic, ecological, environmental and managerial processes and density is within the ecological process together with dependency. Density within ecological process is assumed as result of total number of firms in the population and it has an effect on entry to and exit from the population (Xu, 2017; Getz and Andersson, 2016; Hijalager, 2000). As density increases in a population, legitimation is likely to be increases and "density-dependent inhibitors" relating specifically to how many organisms there are in a given area (Anderson et al. 2013). From this view point it is possible to mention about resource partition model. Carroll \& Swaminathan (2000), explain resource partitioning model in their study that assumes relationship between market trends of general and private organizations, subsequent increase in the number of private organizations available in any population and the fact that population density results in increased number of highly privatized companies. Getz and Andersson, (2016), proposed "as evidence that density dependence is applicable, researchers should first determine rates of change and assess any evident cycles, then correlate growth in start-ups and cumulative numbers of events with hypothetical causal factors". At this study general and private organizations are formed as sub populations of Turkey's accommodation population and their existences are assumed to be in relation to each other's general and differentiated business strategies. This study uses repeated measures ANOVA in order to investigate the differences between general and private accommodation organization types by population density. Analysis included number of general and private type firms as dependent variable and year groups as independent factors. Post-hoc analysis was used for comparisons in pairs. As 
proposition of Getz \& Andersson (2016), in this study, rates of changes in population density are measured firstly then correlated events with hypothetical factors.

\subsection{Research Model and Hypothesis}

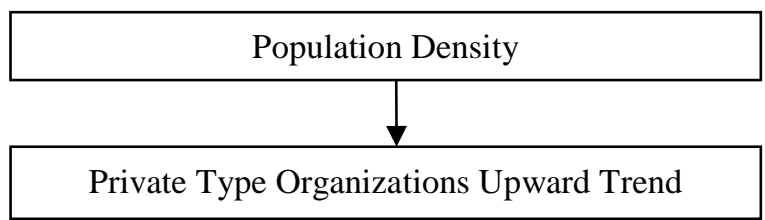

Figure 1: Research Model

Figure 1 shows the purpose of this study and the research model created with respect to the above mentioned theoretical framework. Carroll \& Swaminathan (2000), employed resource partitioning model for measuring general and private organization founding and mortality rate in beer population in USA.

Hijalager (2000), compares existence of restaurants and fast food firms as sub population of food organization population in Denmark from organizational ecology perspective's demographic processes. Hijalager (2000), illustrated that age, size, affiliation, ownership and composition of labor variables have effect on existing rates of restaurant establishments, comparatively restaurants have more long-term life than fast food firms. Both studies used mortality and founding statistics of each establishment that included in their research samples, especially second one had reached composition of labor, ownership affiliation of firms' data and they obtained exact population events like population dependency and resource partitioning of general and private type of organizations. Because of data constraints about mortality rates of each type organization only foundation rate of establishments were used in this study.

According to Hannan et al. (2007) density dependence posits "relationship between density, the number of organizations in a population, and legitimation of the form of organization and competition among the population's members". Nickel \& Fuentes $(2004 ; 45)$; Ersoy et al. (2015) explain the relationship between legitimacy and the density dependence of the competition, as follows: the level of competition in the relationship is affected by the concentration dependence of the population, accordingly, level of competition increases as the concentration of the population increases while organizations in the population start to dissolve with the increased competition. 
In this study organizations were defined with narrowed segment width are defined as private organizations while organizations with a wider segment width are defined as generalist organizations. Private organizations will always outperform generalist organizations in specific environment without change as they feed on an unvaried resource base which allows for increased efficiency and productivity for such firms. As they are varied and dealing with more than one segment, generalist organizations have unproductive resources, therefore their chance of survival is lower than the specialist organizations. It can also be assumed that they are interdependent and compete with each other (Hijalager, 2000).

H1: The accommodation population density in Turkey was increased between 1990 and 2015, means increased competitive environment in the Turkey's accommodation population.

H2: Specialist accommodation sub population (Group 3) had an upward trend between 1990 and 2015 means outperformed generalist accommodation sub population.

Carroll and Swaminathan $(2000 ; 719-720)$ explain the theoretical framework of resource partitioning with respect to the heterogeneous or homogeneous structure of the market organizations which adopt a general or private strategy operate in, as follows:

"Resource concentration is based on the idea that the number of organizations operating in a market characterized with heterogeneous resources increase and that the purpose of businesses operating in a heterogeneous market is positioned in different segments. Private organizations set a specific homogeneous target for themselves while general organizations prefer heterogeneous segments. In this case, as a result of large and general organization structure or the organization's competition with a smaller organization, the market for the small and private organization becomes a free resource. Thus, large organizations gain an even more general structure which leads to further growth. Resource partitioning, on the other hand, refers to continued use of resources by small organizations with a private strategy if they can survive in the face of the pressure of a large organization with a general strategy."

H3: General accommodation sub population (Group1 and Group2) had an upward trend 1990 and 2015 means competitive pressure on specialist accommodation sub population. 


\section{FINDINGS}

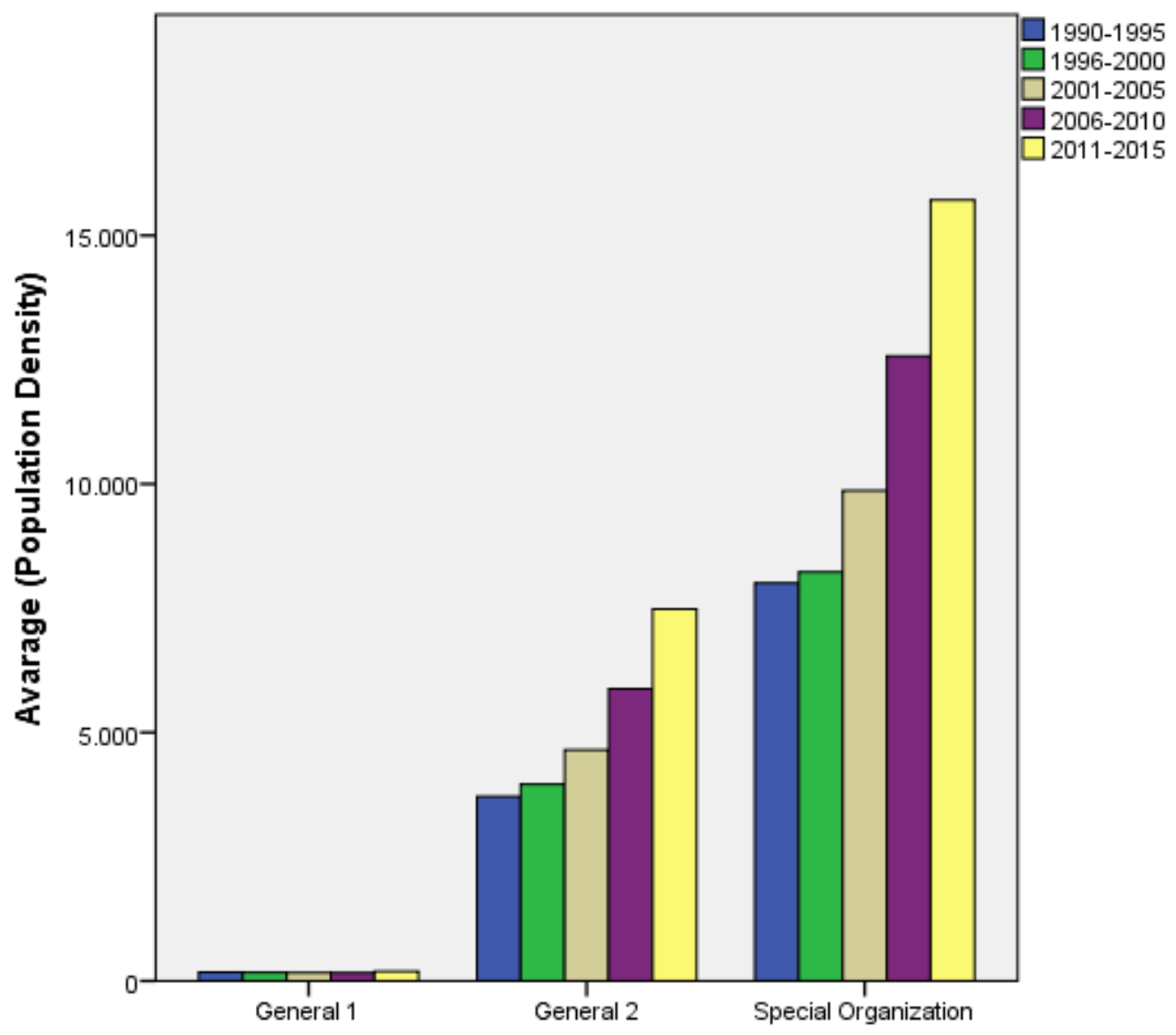

Figure 2: Organization Type

Fig. 2 shows the steadily increased population number of enterprises in Turkey throughout the period 1990 and 2015, thus, H1 receive empirical support. It can be seen, the growth in the private organizations has been particularly pronounced during this period compared with the generalist sub population's number. Jones \& Quadri - Felitti (2013), stated that the growth of the private hotels like boutique and lifestyle hotels has been one of the most watched trends. Upward trend of private accommodation types in Turkey similar with this global phenomenon. 
Table 2: Impact of Organizational Types in Population Densities

\begin{tabular}{|l|l|r|r|r|r|r|r|}
\hline Effect & & Value & F & $\begin{array}{c}\text { Hypothes } \\
\text { is df }\end{array}$ & Error df & $\begin{array}{c}\text { Sig. } \\
\text { Partial Eta } \\
\text { Squared }\end{array}$ \\
\hline Year groups & Pillai's Trace &, 004 &, $141^{\mathrm{b}}$ & 4,000 & 145,000 &, 967 &, 004 \\
\cline { 2 - 9 } & Wilks' Lambda &, 996 &, $141^{\mathrm{b}}$ & 4,000 & 145,000 &, 967 &, 004 \\
\cline { 2 - 9 } & Hotelling's Trace &, 004 &, $141^{\mathrm{b}}$ & 4,000 & 145,000 &, 967 &, 004 \\
\cline { 2 - 9 } & Roy's Largest Root &, 004 &, $141^{\mathrm{b}}$ & 4,000 & 145,000 &, 967 &, 004 \\
\hline Years and Organizations & Pillai's Trace &, 015 &, $538^{\mathrm{b}}$ & 4,000 & 145,000 &, 708 &, 015 \\
\cline { 2 - 9 } & Wilks' Lambda &, 985 &, $538^{\mathrm{b}}$ & 4,000 & 145,000 &, 708 &, 015 \\
\cline { 2 - 9 } & Hotelling's Trace &, 015 &, $538^{\mathrm{b}}$ & 4,000 & 145,000 &, 708 &, 015 \\
\cline { 2 - 9 } & Roy's Largest Root &, 015 &, $538^{\mathrm{b}}$ & 4,000 & 145,000 &, 708 &, 015 \\
\hline
\end{tabular}

N(150), Greenhouse-Geisser; (,275), Huynh-Feldt; $(, 278)$

As seen on Table 2, the Manova test results, the partial eta squared test result was within the bounds of 0.95 . Accordingly, there is a significant difference in the density of the accommodation population over the years.

Table 3: Accomodation Population Density and Partition Relations Between Years of 19902015 in Turkey

\begin{tabular}{|c|c|c|c|c|c|c|c|}
\hline & & & Organiza & Types & & & \\
\hline & & & Gene & & Private Org & zation & $* p$ \\
\hline & Avarage & Std.D. & Avarage & Std.D. & Avarage & Std.D. & $\rightarrow$ \\
\hline 1990-1995 & B 176,9 & 177,5 & AB 3713,2 & 8400,8 & A $8007,6 \mathrm{c}$ & 18021,9 & ,047 \\
\hline 1996-2000 & B 171,1 & 176,6 & AB 3958,2 & 8713,0 & A $8227,4 \mathrm{c}$ & 17901,3 & ,043 \\
\hline $2001-2005$ & A 166,3 & 183,4 & A 4646,3 & 11067,6 & A 9863,6 b & 23199,9 & ,063 \\
\hline $2006-2010$ & A 165,0 & 211,5 & A 5880,9 & 15856,3 & A 12574,8 a & 33282,3 & ,109 \\
\hline $2011-2015$ & A 190,7 & 248,9 & A 7484,5 & 22646,7 & A 15715,4 a & 47266,1 & , 183 \\
\hline$* * p \downarrow$ & & & 12 & & ,04 & & \\
\hline
\end{tabular}

In Table 3, different groups were shown in different letters (a,b,c). When the difference between the groups was examined by years, the difference between the accommodation groups between 1990-1995 and 1996-2000 was found to be statistically significant ( $\mathrm{p}<0,05)$. Terms of 1990-1995 and 1996-2000 were similar but different from later terms. Between 1990-1995 and 1996-2000 the group of private organizations has more facilities than the group of general organizations. Term of 2001-2005 was different from all other groups. 2006-2015 periods showed a marked increase as compared to the previous periods, this increase has caused statistical differences.

Statistically significant difference was detected between the groups of accommodation 
organizations between the years of 1990 - 1995 and 1996 - $2000(\mathrm{p}<0,05)$. The upward trend of private organizations was continued after the year of 2001 but its " $p$ " value bigger than 0.05 . Each group is evaluated separately, the difference by years was found only in the group of private organizations and the difference was statistically significant $(\mathrm{p}<0,05)$. There was an upward trend in all groups compared to the years whereas this difference was significant only in the group of private organizations thus, $\mathrm{H} 2$ receive empirical support. In General 1 and General 2 groups, the change in the number of facilities compared to the years was not statistically significant ( $p>0,05)$ thus, H3 doesn't receive empirical support.

\section{CONCLUSION}

\subsection{Perspective of Research Methodology}

The study illustrates the accommodation population density of general and private organization types in Turkey between the years of 1990 and 2015. Ecological events are explained by using Ministry of Tourism and Culture's data with the perspective of organizational ecology in Turkey's accommodation population. In order to be able to distinguish the sub-population groups of accommodation organizations correctly, both ministerial classifications and the determinations of tourism scholars were used. Hannan and Freeman (2009), divided restaurants as ethnic restaurants, fast food forms, luxury dining houses and coffee shops according to their operating time (24 hours in a day), price range, service style and menu items and they proposed that "there appears to be great variability in terms of specialism/generalism”. In their study, researchers (Pearce \& Moscardo, 1992; Allastair et al., 1996) underline three criteria (talent human resource, location of establishment, running by owner or member of a chain) for accepting a hotel firm as private type. By unifying this view to Ministry of Tourism and Culture' classification, sub group of generalist and specialist accommodation establishment types were obtained. First of all, in this study, the relationship between the organisms of organizational ecology approach has been fulfilled by distinguishing between general and private organizations. This study found empirical evidence from organizational ecology perspective that accommodation population density in Turkey has steadily upward tendency (see Figure 1). Finally population density hypothesis receives empirical support. Even if there is growth across the population, this is only statistically significant in private organizations. According to these results obtained $\mathrm{H} 2$ was accepted but H3 was rejected. Resource partition means small organizations with specific strategies can survive despite the pressure of large organizations (Carroll \& Swaminathan, 2000). According to the research findings, it can be said that the resource partitioning was realized. 


\subsection{Theoritical Implications}

Organizational ecology perspective is used as research frame to addresses organizational behaviors. Having similar propositions with open system theory, organizational ecology approach remained mainly at the outside of tourism area. This study seeks to research diversity approach by conducting empirical investigation about accommodations population in Turkey. Different from a number of earlier studies in tourism (Hijalager, 2000; Andersson et al. 2013; Getz \& Andersson, 2016) this study focused on organizational ecology events of accommodation populations and divided hotel types as specialist and generalist hotel establishments as sub populations. Current study's issues are theoretically interesting and can make contribution to other studies by presenting new horizons about investigating dynamic relations between organization's age, size affiliations and their being able to survive.

\subsection{Practical Implications}

Among the most important factors affecting the survival and lifecycle of businesses are their ability to adapt to global conditions and their sensitivity to their environment (Ülgen \& Mirze, 2010; 31). By evaluating consequences of this study, owner of hotel establishments would have important strategic opinion. This study can make contribution to uncovering the mechanisms that drive strategic human resources of hotel establishments to support innovations and to ensure sustainable competitive advantage for hotel business.

\subsection{Limitation and Future Research}

This study fail to obtain more detailed data about each of generalist and specialist hotel establishments' age, size and mortality numbers registered as annually. Ministry of Tourism and Culture's statistics of annual founding number of hotel classes in Turkey were the most comprehensive data resource for the aim of this study. Future studies also should develop more sensitive measures of environmental variables by adding GDP per capita, talented employee density etc. 


\section{REFERENCES}

Aktaş, A. (2002), Tourism Management, Antalya: Azim Printing Press.

Aldrich, H.E. and Ruef, M. (2006), Organizations Evolving, CA: Thousand Oaks.

Andersson, T., and Getz, D., (2016), “Analyzing Whole Populations of Festivals and Events: An Application of Organizational Ecology”, Vol:8(3), 249-273.

Andersson, T., Getz, D. and Mykletun, R., (2013), "Sustainable Festival Populations: An Application of Organizational Ecology”, Tourism Analysis, Vol:18, 621-634.

Baum, J.A.C. and Amburgey, T.L. (2002), Organizational Ecology. In: Baum, J.A.C. (Ed.), The Blackwell Companion to Organizations. Blackwell, Malden, MA, pp. 304-326.

Bookman, M. Z. and Bookman, K. R. (2007)., Medical Tourism In Developing Countries, New York, NY: Palgrave Macmillan. Retrieved from https://ebookcentral.proquest.com.

Callan, R. and Fearon, R. (1997), "Town House Hotels - An Emerging Sector", International Journal of Contemporary Hospitality Management, Vol: 9 (4), 168 - 175.

Carroll, G. and Hannan, M. (1989), "Density Dependence in the Evolution of Populations of Newspaper Orgaizations", American Sociological Review, 54; 524-541.

Carroll, G. and Hannan, M. (2000), “Why Corporate Demography Matters: Policy Implications of Organizational Diversity, California Management Review, Vol:42(3), 148-163.

Carroll, G. and Swaminathan, A. (2000), "Why the Microbrewery Movement? Organizational Dynamics of Resource Partitioning in the U.S. Brewing Industry”, American Journal of Sociology, Vol: 106(3), 715762.

Carroll, G., (1985), "Concentration and Specialization; Dynamics of Niche Width in Populations of Organizations”, American Journal of Sociology, Vol:90; 1262-1283.

Chen, F. Hsu, T. and Tzeng, G. (2011), “A Balanced Scorecard Approach To Establish A Performance Evaluation And Relationship Model For Hot Spring Hotels Based On Hybrid MCDM Model Combining DEMATEL and ANP”, International Journal of Hospitality Management, Vol:30; 908 - 932.

Chu, Raymond. and Choi, Tat. ( 2000 ), “ An Importance - Performance Analysis of Hotel Selection Factors in the Hong Kong Hotel Industry: A Comparison of Business and Leisure Travelers", Tourism Management, Vol: 21 (4), $363-377$.

Erdil, Oya. Kalkan, Adnan.and Alparslan, Ali. Murat., (2010), "From Organizational Ecology Theory to Strategic Management", Doğuş University Journal, 12 ( 1 ); 17 - 31.

Ersoy, Yılmaz, Sevdiye. and Çetinel, Emine., (2015), “Organizational Death: An Evaluation in the Context of Adaptation Theories”, Çankırı Karatekin University Journal of the Institute of Social Sciences,, 6(1); 211 -230 .

Han, Heesup., (2013), “The Healthcare Hotel: Distinctive Attributes For International Medical Travelers", Tourism Management, Vol; 36, 257 - 268.

Heung, V. C. S., Kucukusta, D., ve Song, H. (2011)., "Medical Tourism Development In Hong Kong: An Assessment Of The Barriers", Tourism Management, 32, 995 - 1005.

Hijalager, M.A., (2000), “Organizational Ecology in the Danish Restaurant Sector”, Tourism Management, 21; $271-280$.

Hing. Nerilee, McCabe. Vivienne, Lewis. Peter ve Leiper. Neil, (1998), "Hospitality Trends In The Asia-Pacific: A Discussion of Five Key Sectors", International Journal of Contemporary Hospitality Management, Vol. $10(7), 264-271$.

Hjalager, M.A., (1999),'The Ecology of Organizations in Danish Tourism: A Regional Labour Perspective, Tourism Geographies, Vol1(2):164-182.

Hsieh, S. F. (2007). A Study On The Consumers' Choice Behavior Of The Site For Hot Spring Bathing, Tourism Management Research, 7(2), 165-186.

Humphreys. Claire, (2014), "Understanding How Sporting Characteristics And Behaviours Influence Destination Selection: A Grounded Theory Study of Golf Tourism”, Journal of Sport \& Tourism, Vol: 19 (1), 29-54. 
Ivery, J.M., (2007), “Organizational Ecology”, Administration in Social Work, Vol:31(4), 7-19.

Jones, David L., Day, Jonathon., Quadri-Felitti, Donna., (2013)., "Emerging Definitions of Boutique and Lifestyle Hotels: A Delphi Study", Journal of Travel \& Tourism Marketing, Vol; 30, 715 - 731.

Kaya, Çiğdem. \& Ataman, Göksel., (2014), “Legal - Political and Economic Thoughts: The Effect of Local and Foreign Organizational Populations on Density; Turkey Banking Population 1923 - 2011”, http://edergi.marmara.edu.tr/maruoneri/article/view/1012000343, Date of Access; 17/05/2015.

Loree. D, ( 2008 ), “ Density Dependent Strategic Actions: Outcomes of Market Commitment in the Global Integrated Circuit Industry”, Journal of Engineering and Technology Management, 25,23 - 57.

Lu, I. \& Shiu, J. Y (2009). Customers' Behavioral Intentions In The Service Industry: An Empirical Study Of Taiwan Spa Hotels, Asian Journal on Quality, 10(3), 73 - 85.

Martin-Fuentes. Eva, ( 2016 ), “Are Guests Of The Same Opinion As The Hotel Star-Rate Classification System?”, Journal of Hospitality and Tourism Management, Vol: 29, 126 - 134.

Mathews, B.W., (2015)," Corrections, İmplementation, and Organizational Ecology: An İntroduction To The Purveyor Core - Skills Model”, Criminal Justice Studies, Vol:28(4), 464-483.

Moital, Miguel. Dias, Nuno Ricardo \& Machado, Danielle. F.C, (2013), “A Cross National Study Of Golf Tourists’ Satisfaction", Journal of Destination Marketing \& Management, Vol: 2, 39-45.

Morrison, A. M., Pearce, P. L., Moscardo, G., Nadkarni, N., and O’Leary, J. T. (1996). "Specialist Accommodation: Definition, Markets Served, and Roles in Tourism Development", Journal of Travel Research, 35(1), 18-26.

Pearce, Philip., and Moscardo, G., (1992), The Boutique / Specialist Accomodation Sector: Perceived Government Needs and Policy Initiatives, Townswille, Quennisland; James Cook University.

Perrow, C. (1986). Complex Organizations: A Critical Essay, New York: Random House

Petersen, T. and Koput, K.W. (1991), "Density Dependence in Organizational Mortality; Legitimacy or Unobserved Heterogeneity”, American Sociological Review, 56; 399-409.

Serrano, Juan., Turrion, Jaime., Velazquez, Francisco., (2014), “Are Stars A Good İndicator Of Hotel Quality? Assymetric Information and Regulatory Heterogeneity in Spain”, Tourism Management, Vol; 42, 77 - 87.

Strannegard, Lars. and Strannegard, Maria. (2012), "Works of Art : Aesthetic Ambitions in Design Hotels", Annals of Tourism Research, Vol: 39 (4), 1995 - 2012

Stretesky, P., Huss, S., Lynch, M., (2012), “Density Dependence and Environmental Justice Organizations, 1970 - 2008", The Social Science Journal, Vol:49, 343 - 351.

Uludağ. Ahmet S. ve Deveci. (2013), "Use of Multi Criteria Decision Making Methods in Site Selection Problems and An Application”, AİBÜ Sosyal Bilimler Enstitüsü Dergisi, 13 ( 1 ); 257 - 287.

Ülgen, H. \& Mirze, K.S., (2010), Strategic Management in Business, İstanbul: Beta Publishing.

Xu, Y., (2017), "Modeling the Adoption of Social Media by Newspaper Organizations: An Organizational Ecology Approach", Telematics and Informatics, Vol:37, 151-163.

Zang, Hangin Qiu., Guilet, Denizci, Başak. ve Gao, Wendy., (2012), “ What Determines Multinational Hotel Group's Locational Investment Choice in China?” International Journal of Hospitality Management, Vol: $31,350-359$.

http://yigm.kulturturizm.gov.tr/TR,9860/turizm-belgeli-tesisler.html Date of Access; 20 / 03 / 2015

https://www.hilton.com.tr/haberler/ Date of Access; 12/07/2018 